\title{
原著
}

\section{閉経が歯肉溝滲出液中のインターロイキン-1 濃度に及ぼす影響}

$\begin{array}{llll}\text { 夫馬大介 } & \text { 稲垣幸司 } & \text { 石原裕一 } & \text { 小出雅則 } \\ \text { 林 潤一郎 } & \text { 田中繁寿 } & \text { 祖父江尊範 } & \text { 伊藤貴志 } \\ \text { 岩田武久 } & \text { 鈴木万里代 } & \text { 黒須康成 } & \text { 佐藤連造 } \\ \text { 坂野雅洋 } & \text { 杉石 } \text { 泰 } & \text { 吉成伸夫 } & \text { 野口俊英 }\end{array}$

愛知学院大学歯学部歯科保存学第三講座

(2004 年 10 月 2 日受理)

\author{
Effect of Menopause on Interleukin-1 Concentration in \\ Gingival Crevicular Fluids \\ Daisuke Fuma, Koji Inagaki, Yuichi Ishihara, Masanori Koide, \\ Junichiro Hayashi, Shigehisa Tanaka, Takanori Sobue, Takashi Ito, \\ Takehisa Iwata, Mariyo Suzuki, Yasunari Kurosu, Renzo Sato, \\ Masahiro Sakano, Tai Sugiishi, Nobuo Yoshinari and Toshihide Noguchi \\ Department of Periodontology, School of Dentistry, Aichi-Gakuin University \\ Accepted for publication 2 October 2004
}

Estrogen is thought to play a role in inhibiting bone resorption and reduced estrogen levels correlate with postmenopausal osteoporosis. Menopause and oophorectomy have been associated with increased production of bone resorption-inducing cytokines. The purpose of the present study was to compare the concentrations of Interleukin-1 (IL-1) in the gingival crevicular fluid (GCF) of premenopausal and postmenopausal women. IL-1 $\alpha$, IL-1 $\beta$, IL-1 receptor antagonist (ra) and the total IL-1/IL-1 ra ratio (IL-1 activity index ; IL-1 AI) were measured in $144 \mathrm{GCF}$ samples from 72 sites in 12 premenopausal patients ( $\mathrm{Pr}$

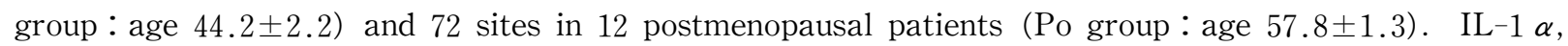
IL-1 $\beta$ and IL-1 ra were measured by specific non-crossreactive enzyme linked immunosorbent assays. The probing depth, clinical attachment level, bleeding on probing, tooth mobility, gingival index, and alveolar bone loss of each site were recorded at the time of GCF sampling. The marginal gingival inflammation in both groups was well controlled and the clinical inflammatory assessments of the gingival condition were indistinguishable in both groups. The concentrations of IL-1 $\alpha$, IL- $-1 \beta$, IL- -1 ra and IL- 1 AI in the Po group were significantly higher than those in the Pr group (IL-1 $\alpha 110.0 \pm 15.1 \mathrm{pg} / \mathrm{m} l ; 61.3 \pm 8.8$ $\mathrm{pg} / \mathrm{m} l, P<0.01, \mathrm{IL}-\beta 27.3 \pm 4.8 \mathrm{pg} / \mathrm{m} l ; 15.6 \pm 3.4 \mathrm{pg} / \mathrm{m} l, P<0.05, \mathrm{IL}-1 \mathrm{ra} 77.2 \pm 13.6 \mathrm{ng} / \mathrm{m} l ; 39.9 \pm 4.3$ $\mathrm{ng} / \mathrm{m} l, P<0.01$, IL-1 AI, $27.3 \pm 4.8 \mathrm{pg} / \mathrm{m} l ; 15.6 \pm 3.4 \mathrm{pg} / \mathrm{m} l, 86951<0.05)$. Conclusively, the increased

\footnotetext{
連絡先：稲垣幸司

干 464-8651 名古屋市千種区未盛通 2-11 愛知学院大学歯学部歯科保存学第三講座

Koji Inagaki

Department of Periodontology, School of Dentistry, Aichi-Gakuin University

2-11 Suemoridori, Chikusaku, Nagoya 464-8651, Japan

E-mail kojikun@dpc.aichi-gakuin.ac.jp
} 
IL-1 $\alpha$, IL-1 $\beta$, IL-1 ra concentrations and IL-1 AI in the Po group suggest that menopause does correlate with increased IL-1 cytokine in GCF. J Jpn Soc Periodontal, 46:259-265, 2004.

Key words : menopause, gingival crevicular fluid (GCF), interleukin-1 (IL-1), enzyme linked immunosorbent assay (ELISA)

要旨：エストロゲンの欠乏は，閉経後骨粗鬆症に関連し，エストロゲンは，骨吸収抑制作用があると考元られ ている。閉経抢よび卵巣摘出により, 骨吸収性サイトカインの産生が増加する。そこで本研究では, 閉経後女性 の歯肉溝滲出液（gingival crevicular fluid, GCF) 中の IL-1 濃度を, 閉経前女性との間で比較した。IL-1 $\alpha$, IL-1 $\beta$, IL-1 ra 濃度抒よび総 IL-1/IL-1 ra 比（IL-1 活性度，IL-1 AI） は，閉経前女性（Pr 群，44.2 2.2 歳） 12 名の 72 歯，閉経後女性（Po 群， $57.8 \pm 1.3$ 歳） 12 名の 72 歯，合計 144 歯から測定した。IL-1 $\alpha$, IL-1 $\beta$ および IL-1 ra 濃度の測定には, サンドウィッチ酵素免疫測定法 (enzyme linked immunosorbent assay, ELISA）を用いた。GCF 採取時に, 歯周病所見（プロービングポケット深さ,クリニカルアタッチメントレベ ル, プロービング時の歯肉出血, 歯の動摇度, 歯肉炎指数, 歯槽骨吸収率) を診査した。歯周病所見は, 両群間 に差はなく, 辺縁歯肉の炎症はコントロールされていた。Po 群の IL-1 $\alpha$, IL-1 ra 濃度は, Pr 群に比べ高く $(P<0.01)$, また, IL-1 $\beta$ 濃度, IL-1 AI も高かった $(P<0.05)$ 。したがって, 閉経は, GCF 中の IL-1 産生 の増加に影響することが示唆された。

索引用語：閉経, 歯肉溝滲出液, インターロイキン-1, ELISA 法

\section{緒言}

閉経後骨粗鬆症は，閉経による女性ホルモンの変動 が発症に関与する。すなわち，エストロゲン欠乏によ り骨代謝が充進し，骨吸収と骨形成がともに元進する が，骨吸収の光進が骨形成を上まわり骨量が減少する と考えられている1)。エストロゲンは，骨代謝調節因 子としてのサイトカイン分泌涼響を及ぼすが，関与 する骨形成性サイトカインとしてトランスフォーミン グ増殖因子 (transforming growth factor- $\beta$, TGF$\beta$ ), インスリン様増殖因子 (insulin like growth factor-1, IGF-1), 骨吸収性サイトカインとしてのイン ターロイキン-1 (interleukin-1, IL-1), IL-6, 腫瘍 壊死因子- $\alpha$ (tumor necrosis factor- $\alpha, \mathrm{TNF}^{-} \alpha$ ) が報告されている2)。

Pacifici らは，閉経後骨粗鬆症患者の未梢血単球で の IL-1 産生元進とエストロゲン補充によるその正常 化㧍よび卵巣摘出患者での IL-1や TNF- $\alpha$ の産生六 進とエストロゲンによるその抑制作用について報告し ている3)。したがって，エストロゲンは，局所におい てこれら骨吸収性サイトカインの産生を抑制すること で，骨吸収を調節している可能性が示唆されている。

これまでに, 閉経後骨粗鬆症に起因する全身の骨量 減少と歯周病にみられる局所の歯槽骨吸収との関係に 関心がもたれ，その因果関係を解明すべく数々の研究 が報告されている ${ }^{4-6)}$ 。しかし，閉経による歯肉溝滲 出液 (gingival crevicular fluid, GCF) 中のサイト
カインについての報告は少ない年早。すなわち, Payne ら〕は，エストロゲン久乏患者では，正常者よ り GCF 中の IL-1 $\beta$ と IL-8 が高いことを最初に報告 した。次に, Reinhardt ら ${ }^{81}$ は, 同一被検者で, GCF 中の IL-1 $\beta$ と IL-6 を比較した結果, エストロゲン 欠乏が局所の IL-1 $\beta$ の産生を六進させる可能性があ ることを示唆した。引き続き，Reinhardt ら ${ }^{9} は$ は, 閉 経後女性歯周炎患者に歯周治療を行い, 歯周組織健康 者を対照として，血中エストロゲン， 臼歯部の歯槽骨 高さの変化と GCF 中の IL-1 $\beta$ について, ベースラ イン時と 2 年後で比較・検討している。その結果，歯 周炎進行群では, エストロゲン欠乏が, GCF 中の IL-1 $\beta$ の産生元進に関与していると報告したが, はっきりとした見解にいたっていない。

そこで, 本研究では, 閉経後骨粗鬆症と局所の骨代 謝の関連性を把握する一助として，エストロゲン欠乏 によって骨代謝調節因子であるサイトカイン分泌のバ ランスが崩れる閉経後女性と閉経前女性に扔ける GCF 中の IL-1の動態を比較検討した。

\section{被験者および方法}

本研究は, 愛知学院大学歯学部倫理委員会の承認 (平成 15 年 10 月 8 日承認) のもとに行い, 十分なイ ンフォームドコンセントを得た。

\section{1. 被験者と被験歯}

愛知学院大学歯学部附属病院歯周病科を受診し, 歯 周基本治療により急性炎症がコントロールされ, 骨密 
度（bone mineral density，BMD）に影響を及ぼす 疾患をもたない閉経後女性群（Po 群）12名（52～63 歳, $57.8 \pm 1.3$ 歳, 閉経年齢 $50.7 \pm 1.2$ 歳, 閉経後年 数 $7.1 \pm 1.0$ 年）の上顎 6 前歯， 72 歯を選択した。ま た，同様に歯周基本治療により炎症がコントロールさ れた閉経前女性群（Pr 群）12 名（年齢 32〜 55 歳, $45.4 \pm 1.8$ 歳）の 72 歯を対照として比較した。なお, 被検者の背景因子として, 喫煙や飲酒習慣と閉経後女 性の閉経年齢，閉経後年数を確認した。

\section{2. 臨床所見}

GCF 採取前, 各被験部位の歯肉炎指数 (gingival index, GI ${ }^{10)}$ を診査し, GCF 採取後, プロービング ポケット深さ (probing depth, PD), クリニカルア タッチメントレベル (clinical attachment level, $\mathrm{CAL}$ )，プロービング時の歯肉出血 (bleeding on probing, BOP) および歯の動摇度 (tooth mobility，TM）を評価した。なお PD と CAL は，15 mm の歯周 プローブ (CPUNC 15, Hu-Friedy, Chicago, USA）を用いて，6点法により $1 \mathrm{~mm}$ 単位 で測定した。また，デンタル X 線写真から Schei ら の方法 ${ }^{11)}$ 準じて, 被験歯 6 歯近遠心の平均歯槽骨吸 収率 (alveolar bone loss, ABL) を算出した。

\section{GCF の採取}

GCF サンプルの採取は, 黒柳らの方法 ${ }^{12)} に$ 準じて 吸湿採取法を用いた。被験歯を唇側の近心, 中央, 遠 心部の 3 部位に対してロールワッテで簡易防湿し, 唾 液の混入を防いだ後, 綿球にて歯肉縁上プラークを可 及的に除去した。スリーウェイシリンジで軽く乾燥 後, ペリオペーパー (PerioPaper Strips ${ }^{\circledR}$, Oraflow Inc, NewYork, USA）を歯肉溝に挿入 10 秒間静置 し, GCFを吸湿採取した。採取後, 直ちにペリオ ペーパーの湿重量を測定した。

ペリオペーパーに採取された総 GCF 量は, GCF の比重を 1.0 と仮定し, ペリオペーパーの重量から容 量を換算し求めた。採取後ペリオペーパーに，0.5\% 牛血清アルブミン (BSA, Sigma, St Louis, USA）入りのリン酸緩衝生理食塩水（PBS，日本製 薬株式会社, 東京) $100 \mu l$ を加え, 20 分間連続的に 振盪し, ペリオペーパーに含まれる GCFを十分に PBS に溶出させ，可及的に GCF を含むPBS を回収 し, 10 分間 10,000 rpm にて遠心処理後，その上清の みを GCF サンプルとした。なお, GCF サンプルは, 測定までの間 $-80^{\circ} \mathrm{C}$ に保存した。

\section{IL-1 $\alpha$, IL-1 $\beta$ および IL-1 ra の測定}

IL $-1 \alpha$ と IL-1 $\beta$ 濃度の測定は, GCF サンプルを 20 倍希釈し, IL-1 ra 濃度の測定は, GCF サンプル を200 倍希釈して行った。測定は, Quantikine ${ }^{\circledR}$
表 1 背景因子

\begin{tabular}{lcc}
\hline & $\begin{array}{c}\text { 閉経前女性群 } \\
(\mathrm{n}=12)\end{array}$ & $\begin{array}{c}\text { 閉経後女性群 } \\
(\mathrm{n}=12)\end{array}$ \\
\hline 年齢 (歳) & $44.2 \pm 2.2$ & $57.8 \pm 1.3$ \\
閉経年齢 (歳) & - & $50.7 \pm 1.3$ \\
閉経後年数 (年) & - & $7.1 \pm 1.0$ \\
喫煙者 (人) & 1 & 0 \\
飲酒習慣 (人) & 2 & 2 \\
\hline
\end{tabular}

平均土標準偏差

human IL-1 $\alpha$, IL-1 $\beta$, IL- 1 ra ELISA kit (R \& D systems, Minneapolis, USA) を使用し, サンド ウィッチ酵素免疫測定法 (enzyme linked immunosorbent assay, ELISA) を用いた。IL-1 $\alpha$, IL-1 $\beta$ およびIL-1 ra の検出限界は, それぞれ 0.3 $\mathrm{pg} / \mathrm{m} l, 1.0 \mathrm{pg} / \mathrm{m} l, 0.014 \mathrm{ng} / \mathrm{m} l$ であった。なお, 各 IL-1 濃度は, 各群 1 歯あたりの平均濃度を算出し た。

\section{IL-1 活性度}

IL-1 ra が, IL-1 の活性を阻害することから, 石原 らの方法 ${ }^{13)} に$ 従い, 両者の比率を以下の計算式より求 め, 得られた值を IL-1 活性度 (IL-1 AI) とした。

$(\mathrm{IL}-1 / \mathrm{IL}-1 \mathrm{ra})=($ total $\mathrm{IL}-1 \alpha \mathrm{pg} / \mathrm{m} l+$ total IL -1 $\beta \mathrm{pg} / \mathrm{m} l) /($ total IL-1 ra pg/m $l+10) \times 10^{3}$ 。

なお, 統計解析は, 各群間の比較には, $t$ 検定, 治 療前後の比較には, paired $t$ 検定を用いた（SPSS $11.0 \mathrm{~J}$ for windows)。

\section{結＼cjkstart果}

\section{1. 背景因子}

年齢は, Pr 群 $44.2 \pm 2.2$ 歳, Po 群 $57.8 \pm 1.3$ 歳 で, Po 群の閉経年齢と閉経後年数は, $50.7 \pm 1.3$ 歳, $7.1 \pm 1.0$ 年であった。なお, 現在の喫煙者は, Pr 群 1 名だけで, 飲酒習慣は, 両群各 2 名であった (表 1 )。

\section{2. 臨床所見}

初診時の $\mathrm{PD}$ は, Pr 群 $2.3 \pm 0.1 \mathrm{~mm}, \mathrm{Po}$ 群 $2.5 \pm$ $0.1 \mathrm{~mm}, \mathrm{CAL}$ は, Pr 群 $2.7 \pm 0.1 \mathrm{~mm}, \mathrm{Po}$ 群 $2.8 \pm$ $0.1 \mathrm{~mm}, \mathrm{BOP}$ 率は, Pr 群 $14.8 \pm 5.0 \%, \mathrm{Po}$ 群 $20.4 \pm 6.3 \%$ とほぼ同一であった。また, 歯周基本治 療後の PD は, Pr 群 $2.1 \pm 0.1 \mathrm{~mm}, \operatorname{Po}$ 群 $2.1 \pm 0.1$ $\mathrm{mm}, \mathrm{CAL}$ は, Pr 群 $2.7 \pm 0.2 \mathrm{~mm}, \operatorname{Po}$ 群 $2.7 \pm 0.1$ $\mathrm{mm}, \mathrm{BOP}$ 率は, Pr 群 $10.7 \pm 3.4 \%$, Po 群 $15.7 \pm$ $5.0 \%$ であった。歯周基本治療後 Po 群の PD は, 初 診時に比べ, 減少し $(P<0.05)$, 辺縁歯肉の炎症は, コントロールされていた。また, GI 1 以上の比率は, 
表 2 歯周病所見

\begin{tabular}{|c|c|c|c|c|}
\hline & \multicolumn{2}{|c|}{ 閉経前女性群 $(n=12)$} & \multicolumn{2}{|c|}{ 閉経後女性群（n=12） } \\
\hline & 初診時 & $\begin{array}{c}\text { 歯周基本治療後 } \\
\text { (GCF 採取時) }\end{array}$ & 初診時 & $\begin{array}{l}\text { 歯周基本治療後 } \\
\text { (GCF 採取時) }\end{array}$ \\
\hline & & & & \\
\hline プロービングポケット深さ（mm） & $2.3 \pm 0.1$ & $2.1 \pm 0.1$ & $2.5 \pm 0.1$ & $2.1 \pm 0.1$ \\
\hline クリニカルアタッチメントレベル $(\mathrm{mm})$ & $2.7 \pm 0.1$ & $2.7 \pm 0.2$ & $2.8 \pm 0.1$ & $2.7 \pm 0.1$ \\
\hline プロービング時の歯肉出血率（\%） & $14.8 \pm 5.0$ & $10.7 \pm 3.4$ & $20.4 \pm 6.3$ & $15.7 \pm 5.0$ \\
\hline 歯肉炎指数a 1 以上の比率（\%) & & $19.9 \pm 4.0$ & & $17.1 \pm 5.1$ \\
\hline 歯の動摇度 1 以上の比率（\%) & & 0 & & 0 \\
\hline 歯槽骨吸収率b（\%） & & $14.6 \pm 3.1$ & & $14.4 \pm 1.3$ \\
\hline
\end{tabular}

診查部位は, 上顎 6 前歯の平均

** $: P<0.01$ 平均土標準偏差

${ }^{a}$ Löe \& Silness (1963) ${ }^{10)}$

${ }^{\mathrm{b}}$ Schei et al. $(1959)^{11)}$

表 3 IL-1 濃度

\begin{tabular}{|c|c|c|}
\hline & $\begin{array}{c}\text { 閉経前女性群 } \\
(\mathrm{n}=12)\end{array}$ & $\begin{array}{c}\text { 閉経後女性群 } \\
\quad(n=12)\end{array}$ \\
\hline 被験歯数 & 72 & 72 \\
\hline $\mathrm{IL}-1 \alpha(\mathrm{pg} / \mathrm{m} l)$ & $61.3 \pm 8.8$ & $110.0 \pm 15.2$ \\
\hline $\mathrm{IL}-1 \beta(\mathrm{pg} / \mathrm{m} l)$ & $15.6 \pm 3.4$ & $27.3 \pm 4.8$ \\
\hline $\mathrm{IL}-1 \mathrm{ra}(\mathrm{ng} / \mathrm{m} l)$ & $39.9 \pm 4.3$ & $77.2 \pm 13.6$ \\
\hline IL-1 活性度 & $1.4 \pm 0.2$ & $1.9 \pm 0.2$ \\
\hline$*: P<0.05$ & $P<001$ & \\
\hline
\end{tabular}

Pr 群 $19.9 \pm 4.0 \%$, Po 群 $17.1 \pm 5.1 \%$, TM 1 以上 の比率は, Pr 群 $0 \%, \operatorname{Po}$ 群 $0 \%, \mathrm{ABL}$ は, Pr 群 $14.6 \pm 3.1 \%$, Po 群 $14.4 \pm 1.3 \%$ であり, 両群間に有 意差はなかった（表 2)。

\section{GCF 中の IL-1 濃度}

$\mathrm{Po}$ 群の IL $-1 \alpha$ 濃 度 $(110.0 \pm 15.1 \mathrm{pg} / \mathrm{m} l)$ と IL-1 ra 濃度（77.2 $13.6 \mathrm{ng} / \mathrm{m} l ）$ は, Pr 群の IL-1 $\alpha$ 濃度 $(61.3 \pm 8.8 \mathrm{pg} / \mathrm{m} l)$ と IL-1 ra 濃度 (39.9土 $4.3 \mathrm{ng} / \mathrm{m} l)$ に比べ, 高值を示した $(P<0.01)$ 。ま た, $\mathrm{Po}$ 群の IL-1 $\beta$ 濃度 $(27.3 \pm 4.8 \mathrm{pg} / \mathrm{m} l)$ も, $\mathrm{Pr}$ 群 $(15.6 \pm 3.4 \mathrm{pg} / \mathrm{m} l)$ に比べ, 高值を示した $(P<$

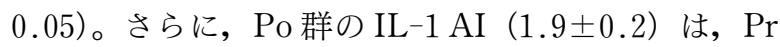
群 $(1.4 \pm 0.2)$ に比べ, 高值を示した $(P<0.05)$ (表 3)。

\section{考察}

骨粗鬆症は，骨折リスクを増すような骨強度上の問
題をもつ人に起こる骨格の疾患と定義されている ${ }^{14)}$ 。 自然閉経や外科的閉経（両側卵巣摘出術）によりエス トロゲンが欠乏すると破骨細胞前駆細胞から破骨細胞 への分化が促進され，その結果，骨代謝が光進して骨 吸収優位となり骨量減少をきたし閉経後骨粗鬆症とな ると考えられている1,3,15)。

エストロゲンは，そのエストロゲン受容体を介し $て^{16)}$ ，骨芽細胞を直接刺激して増殖させること㬏や， 骨芽細胞における $\mathrm{TGF}-\beta, \mathrm{IGF}-1$ あるいは骨基質の 一種であるコラーゲンの産生を高めること裤により, 骨形成促進に働いていると考えられている。また，工 ストロゲンの欠乏は，骨組織に拈いて，炎症性サイト カインである IL-1 や IL-6, TNF- $\alpha$ の産生 ${ }^{19-22), ~ あ ~}$ るいは 2 型シクロオキシゲナーゼ (COX-2) 依存性 のプロスタグランジン $\mathrm{E}_{2}$ (prostaglandin $\mathrm{E}_{2}$, $\left.\mathrm{PGE}_{2}\right)^{21,23)}$ の産生を六進させることが知られている。 さらに，破骨細胞にもエストロゲン受容体が存在する ことが明らかとなり ${ }^{24)}$ ，エストロゲンが破骨細胞に直 接作用し，リソゾームタンパクの発現を抑制して，破 骨細胞活性を制御している可能性も示唆されてい る ${ }^{25)}$ 。したがって，エストロゲンは骨芽細胞を誘導 し, 骨形成を六進する一方で, 骨吸収性のサイトカイ ン産生を抑制することや，破骨細胞の骨吸収活性を直 接抑制することで，骨吸収を抑制・調整していると考 えられている。

IL-1 は，in vitro では有力な骨吸収性サイトカイ ンの 1 つであるが，男女を問わず，骨粗鬆症の際には 患者の末梢血中単球からの多量の IL-1 産生がみられ る。閉経前女性，または閉経後にホルモン補充療法 (hormone replacement therapy，HRT）を受けてい る女性は，未治療閉経後女性よりも IL-1 産生が少な 
い。すなわち，閉経に伴うエストロゲンの欠乏は，末 梢血単球による IL-1 産生の六進を促すと考えられて (る3)。

一方，歯周炎の進行や活性度を表す際の一つの指標 ともいえる GCF は，以前からその量的扔よび質的変 化が歯周病変の動態を示す客観性の高い臨床的デー夕 として用いられており，GCF 中に存在する炎症性メ ディエーター，たとえば，コラゲナーゼやゼラチナー

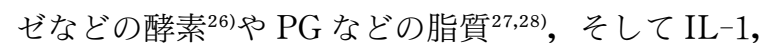
IL-6, TNF- $\alpha$ に代表される前炎症性サイトカイ ン ${ }^{29,30)}$ に関して数多くの研究がなされてきた。

局所の歯槽骨吸収を伴う歯周炎と全身の骨代謝性疾 患による骨量減少を特徵とする骨粗鬆症との関係を解 明するため多くの研究が報告されているが4-6), 閉経 によるエストロゲン欠乏と GCF 中サイトカインの動 態との関係についての報告は，数少ない ${ }^{7-9)}$ 。

Payne $ら^{71}$ は，閉経前女性と閉経後 HRT を受療中 の血中エストロゲン正常群 (43.1歳, $\mathrm{n}=13)$ と閉経 や卵巣摘出によるエストロゲン欠乏群 (51.4 歳, $\mathrm{n}=$ 13）の GCF 中 IL-1 $\beta$ と IL-8 量を比較し, エストロ ゲン久乏群では, IL-1 $\beta$ と IL-8 ともに有意に高值を 示したことを報告した。引き続き, Reinhardt ら ${ }^{8}$ は, 同一被検者で，GCF 中の IL-1 $\beta$ と IL-6 を比較した 結果, エストロゲン欠乏が局所の IL $-1 \beta$ の産生を元 進させる可能性があることを示唆した。しかし，同被 検者の GCF は，プロービング時の歯肉出血を伴う 5 $\sim 6 \mathrm{~mm}$ の $\mathrm{PD}$ から採取していることから，エストロ ゲン欠乏と同時に，局所の炎症の影響を受けたことが 考元られる。さらに, Reinhardt ら ${ }^{9}$ は, 閉経 5 年以 内の閉経後女性を対象に，59 名の中等度から重度の 歯周炎患者に歯周治療を行い，16名の歯周組織健康 者を対照として, 血中エストロゲン， 臼歯部の歯槽骨 高さの変化と GCF 中の IL-1 $\beta$ について, ベースラ イン時と 2 年後で比較・検討している。その結果， 59 名中, 臼歯部の歯槽骨高さの変化で判定した歯周炎進 行群 13 名に扔いては, エストロゲン久乏が，GCF 中 の IL-1 $\beta$ の産生立進に関与していると報告したが, はっきりとした見解にいたっていない。したがって, 本研究では, 歯周基本治療により辺縁歯肉の炎症がコ ントロールされた上顎 6 前歯を被験歯とした。本研究 結果で, Po 群の IL-1 $\beta$ 濃度が Pr 群に比べ有意に高 かったことで, 閉経による骨吸収性サイトカイン産生 の六進は GCF 中でも反映される可能性がより明確に 示唆された。

Ishihara らは, GCF 中の IL-1 $\alpha$, IL-1 $\beta$ 抢よび IL-1 のインヒビターとして知られている IL-1 raを 同時に測定したところ, 歯周炎が重度になるに従い
IL-1 $\alpha$ と IL-1 $\beta$ は増加するのに対し, 歯周炎以外の 炎症性疾患と類似して, IL-1 ra は, 減少したことか ら，歯周炎が重度になるに従い，IL-1 AI は有意に増 加することを明らかにした ${ }^{31}$ 。すなわち, 歯周組織に おける炎症症状を調べるにあたり IL-1 と IL-1 raを 同時に把握することは，歯周炎の病態を的確に評価す るうえで必須である ${ }^{12,13,31)}$ 。しかし，この点において も前述の報告はどれも, IL-1 $\beta$ のみの測定にとど まっている ${ }^{7-9)}$ 。したがって, 本研究では, IL-1 $\alpha$, IL-1 $\beta$ 濃度に対し, IL-1 ra 濃度の影響を加味し, IL-1 AI よよる総合的評価を行った。その結果，Po 群の IL- $1 \alpha$, IL-1 $\beta$ 濃度は, Pr 群に比べ有意に高 く, 辺縁歯肉に炎症をみとめない状態において, Po 群の IL-1 AI も有意に高かったことは, 興味深い所 見と思われる。

IL-1 ra は，歯周炎が重度になるにしたがって有意 に減少すると報告されてきたが12,13,31), 本研究では, IL-1 $\alpha$ と IL-1 $\beta$ 濃度の高かった Po 群の IL-1 ra 濃 度も有意に上昇していることが明らかとなった（表 3)。このことは, 炎症時の歯周組織でのサイトカイン の動態と異なるメカニズムが働いている可能性が示唆 された。

以上の結果から，閉経が，炎症をコントロールされ た歯周組織においてアゴニストである IL-1 $\alpha, \mathrm{IL}-1$ $\beta$ だけでなく，アンタゴニストである IL-1 ra の産生 六進にも影響していることが示唆された。IL-1 ra は, 閉経により増加した IL-1 $\alpha$, IL-1 $\beta$ に拮抗する ために産生されている可能性があり, 今後, IL-1 ra が炎症をコントロールされた歯周組織において産生立 進しているメカニズムについて検討を加えていく予定 である。

謝 辞

今回の研究にご協力, ご指導いただいたはちや整形外科 病院院長蜂谷裕道先生, 同放射線科技師井澤浩之先生, 矢 野博康先生に深く感謝いたします。

なお, 本研究の一部は, 平成 16 年度科学研究費補助金 (基盤研究（B）一般 1 課題番号 16390616）の補助によっ て行われ, 第 46 回秋季日本歯周病学会学術大会 (2003 年 10 月 17 日, 新潟) と第 82 回国際歯科研究学会 (2004 年 3 月 13 日, Honolulu, USA）に扔いて発表した。

\section{文献}

1）須田立雄, 宮浦千里 : 基礎研究の現状と展望, 折茂 肇, 最新骨粗鬆症, 第 1 版, ライフサイエンス出 版, 東京, 1999, 7-9. 
2) Girasole G, Jilka RL, Passeri G, Boswell S, Boder G, Williams DC, Manolagas SC: 17 betaestradiol inhibits interleukin-6 production by bone marrow-derived stromal cells and osteoblasts in vitro: a potential mechanism for the antiosteoporotic effect of estrogens. J Clin Invest, $89: 883-891,1992$.

3) Pacifici R, Brown C, Puscheck E, Friedrich E, Slatopolsky E, Maggio D, McCracken R, Avioli LV : Effect of surgical menopause and estrogen replacement on cytokine release from human blood mononuclear cells. Proc Natl Acad Sci USA, 88 : 5234-5138, 1991.

4) Inagaki K, Kurosu $Y$, Kamiya T, Kondo F, Yoshinari N, Noguchi T, Krall EA, Garcia RI : Low metacarpal bone density, tooth loss, and periodontal disease in Japanese women. J Dent Res, $80: 1818-1822,2001$.

5) Wactawski-Wened J : Periodontal disease and osteoporosis: association and mechanisms. Ann Periodontol, $6:$ 197-208, 2001.

6) Geurs NC, Lewis CE, Jeffcoat K : Osteoporosis and periodontal disease progression. Periodontol 2000, 32 : 105-110, 2003.

7) Payne JB, Reinhardt RA, Masada MP, DuBois LM, Allison AC: Gingival crevicular fluid IL8 : correlation with local IL- $1 \beta$ levels and patient estrogen status. J Periodontal Res, $28: 451-453$, 1993.

8) Reinhardt RA, Masada MP, Payne JB, Allison AC, DuBois LM : Gingival fluid IL $-1 \beta$ and IL-6 levels in menopause. J Clin Periodontol, $21: 22-$ 25, 1994.

9) Reinhardt RA, Payne JB, Maze C, Babbitt M, Nummikoski PV, Dunning D : Gingival fluid IL-1 $\beta$ in postmenopausal females on supportive periodontal therapy. J Clin Periodontol, 25:10291035, 1998.

10) Löe H, Silness J : Periodontal disease in pregnancy I. Prevalence and severity. Acta Odotol Scant, $21: 533-551,1963$.

11) Schei O, Waerhaung J, Lovdal A, Arno A : Alveor bone loss as related to oral hygiene and age. J Periodontol, $30: 7-16,1959$.

12）黒柳隆穂：歯周炎患者における歯肉溝滲出液および 歯肉組織中のインターロイキン-1の動態に関する 研究, 愛院大歯誌, 37：81-90, 1999.

13) Ishihara Y, Ji-Bo Zhang, Mohamed F, AI M Best, Harvey AS, Suzanne EB, John GT : Non-Redundant Roles for Interleukin-1 and interleukin-1 $\beta$ in Regulating Human IgG 2. J Periodontol, 72 : 1332-1339, 2001
14) NIH Consensus Development Panel on Osteoporosis Prevention, Diagnosis, and Therapy. JAMA, 285:785-795, 2001.

15）多賀理吉：エストロゲン，松本俊夫，中村利孝，骨 粗鬆症, 羊土社, 東京, 42-43, 1995.

16) Eriksen EF, Colvard DS, Berg NJ, Graham ML, Mann KG, Spelsberg TC, Riggs BL : Evidence of estrogen receptors in normal human osteoblastlike cells. Science, 241:84-86, 1988.

17) Ernst M, Schmid C, Froesch ER : Enhanced osteoblast proliferation and collagen gene expression by estradiol. Proc Natl Acad Sci USA, 85 : 2307-2310, 1988.

18）武谷雄二：閉経後骨粗鬆症，松本俊夫，中村利孝, 骨粗鬆症，羊土社，東京， 56-57, 1995 .

19) Pacifici R, Rifas L, McCracken R, Vered I, McMurtry C, Avioli LV, Peck WA : Ovarian steroid treatment blocks a postmenopausal increase in blood monocyte interleukin 1 release. Proc Natl Acad Sci USA, 86 : 2389-2402, 1989.

20) Jilka RL, Hangoc G, Girasole G, Passeri G, Williams DC, Abrams JS, Boyce B, Broxmeyer H, Manolagas SC: Increased osteoclast development after estrogen loss : mediation by interleukin-6. Science, 257：88-91, 1992.

21) Miyaura C, Kusano K, Masuzawa T, Chaki O, Onoe Y, Aoyagi M, Sasaki T, Tamura T, Koishihara Y, Ohsugi Y : Endogenous bone-resorbing factors in estrogen deficiency: cooperative effects of IL-1 and IL-6. J Bone Miner Res, 10 : 1365-1373, 1995.

22) Kimble RB, Matayoshi AB, Vannice JL, Kung VT, Williams C, Pacifici R : Simultaneous block of interleukin-1 and tumor necrosis factor is required to completely prevent bone loss in the early postovariectomy period. Endocrinology, 136 : 3054-3061, 1995.

23) Kawaguchi H, Pilbeam CC, Gronowicz G, Abreu C, Fletcher BS, Herschman HR, Raisz LG, Hurley MM : Transcriptional induction of prostaglandin $\mathrm{G} / \mathrm{H}$ synthase -2 by basic fibroblast growth factor. J Clin Invest, $96:$ 923-930, 1995.

24) Oursler MJ, Osdoby P, Pyfferoen J, Riggs BL, Spelsberg TC : Avian osteoclasts as estrogen target cells. Proc Natl Acad Sci USA, 88:66136617, 1991.

25) Oursler MJ, Pederson L, Pyfferoen J, Osdoby P, Fitzpatrick L, Spelsberg TC: Estrogen modulation of avian osteoclast lysosomal gene expression. Endocrinology, 132：1373-1380, 1993.

26）宮下朋久：歯肉炎および歯周炎患者の歯肉溝滲出液 中の TIMP-1 量, コラゲナーゼおよびゼラチナー 
ゼ活性に関する研究. 愛院大歯誌, 32：1-11, 1994.

27) Sengupta S, Fine J, Wu-wang CY, Gordon J, Murty VL, Slomiany A, Silomiany BL : The relationship of prostaglandins to cAMP, IgG, IgM and alpha-2-macroglobulin in gingival crevicular fluid in chronic adult periodontitis. Arch Oral Biol, 35 : 593-596, 1990.

28) Tubb M, Williams FE, Frazier LW : Gingival crevicular fluid prostaglandins and gingival phospholipids in experimentally-induced periodontitis in the dog. Arch Oral Biol, $35: 529-533,1990$.

29) Yavuzyilamz E, Yamalik N, Bulut S, Ersoy F, Saatci U : The gingival crevicular fluid interleukin-1 beta and tumour necrosis factor-alpha levels in patients with rapidly progressive periodontitis. Aust Dent J, 40:46-49, 1995.

30) Reinhardt RA, Masada MP, Kaldahl WP, Dubois LM, Kornman KS, Choi JI, Kalkwarf KF, Allison AC : Gingival fluid IL-1 and IL-6 levels in refractory periodontitis. J Clin Periodontol, $20: 225^{-}$ 231, 1993.

31) Ishihara $Y$, Nishihara $T$, Kuroyanagi $T$, Shirozu N, Yamagishi E, Ohguchi M, Koide M, Ueda N, Amano K, Noguchi T: Gingival crevicular interleukin-1 and interleukin-1 receptor antagonist levels in periodontally healthy and diseased sites. J Periodontal Res, 32 : 524-529, 1997. 